УДК $94(477+438)$ «1920/1939»

DOI 10.24919/2519-058X.5.116987

Василь ФУТАЛА,

orcid.org/0000-0003-2521-4710

доктор історичних наук, професор кафедри історії України Дрогобииького державного педагогічного університету імені Івана Франка

(Україна, Дрогобич)vfutala@ukr.net

\title{
НАЦІОНАЛЬНА ПОЛІТИКА ПОЛЬЩІ НА ЗАХІДНИХ ЗЕМЛЯХ УКРАЇНИ У 1920 - 1930-Х рр.: СУЧАСНЕ УКРАЇНСЬКЕ БАЧЕННЯ*
}

\begin{abstract}
Проаналізовано історіографічні джерела, щзо створені сучасними украйнськими істориками $і$ відбивають стан вивчення державної політики Другої Речі Посполитої у сфері міжнаціональних відносин упродовж 1920 - 1930-х рр. Показано пріоритетні напрями досліджень, персоніфіковано внесок учених у вивчення наукової проблеми, звернено увагу на процес прирощування наукових історичних знань, виокремлено питання, щзо потребують подальшого розгляду.
\end{abstract}

Ключові слова: історіографічне джерело, національне питання, національна політика, українсько-польські взаємини, державна асиміляиія.

Iim. 48.

Vasyl' FUTALA,

Ph D hab. (History),

Professor of the Department of Ukraine's History, Drohobych Ivan Franko State Pedagogical University.

(Ukraine, Drohobych)vfutala@ukr.net

\section{POLAND'S NATIONAL POLICY IN WEST UKRAINIAN LANDS IN THE 1920s - 1930s: A CONTEMPORARY UKRAINIAN VIEW}

The article summarizes the analyses of historiographic sources, that were created by contemporary Ukrainian historians and reflect the state of the study of the state policy of the Second Rzezc Pospolita in the sphere of international relations during the 1920s - 1930s. The priority directions of research are shown, scientists who contributed to the study of the subject under consideration are personified, due attention is drawn to the process of extension of scientific historical knowledge, the questions demanding further research are singled out.

The article proves that historians mainly study Ukrainian-Polish relations and focus their attention on the following questions: the sources and causes of sharpening of the aforementioned relations, ways and methods of assimilation of the Ukrainians, Ukrainian sabotage acts and their place and role in Ukrainian-Polish confrontation, Polish state "pacification» and its purposes and character; the attitude of Ukrainian political circles towards Y. Pilsudskyi's new course, normalization policy and causes of its failure, voivoda G. Yuzewskyi's "Volhynian experiment», Western Ukraine in the orbit of Polish Prometeizm. The achievements of scientists in the investigation of the problem of relations between Polish power and the Jewish minority are significant.

However the problem in view needs further investigation. In particular, historical researches of the recent decades include insufficient number of publications that disclose attempts of Ukrainian-Polish mutual understanding, seek the ways of cooperation of both peoples. More attention should be paid to the demonstration of Polish ethno-national policy through the prism of its foreign policy. A perspective direction for research is the question about the reaction of the world to the sharpening of Polish-Ukrainian relations in the interwar period in the XX century. Probably, Ukrainian studies, dedicated to official Warsaw's policy towards the Germans, Czechs, Armenians and other national minorities that lived in the territories of West Ukrainian lands in the 1920s - 1930s, will gain importance.

Key words: historiographic source, national question, national policy, Ukrainian-Polish relations, state assimilation.

Ref. 48 .

\footnotetext{
* Публікація містить результати досліджень, проведених при грантовій підтримці Держаного фонду фундаментальних досліджень за конкурсним проектом Ф77/80-2017.
} 
Василий ФУТАЛА,

доктор исторических наук, профессор кафедры истории Украины Дрогобычского государственного педагогического университета имени Ивана Франко

(Украина, Дрогобыч)vfutala@ukr.net

\title{
НАЦИОНАЛЬНАЯ ПОЛИТИКА ПОЛЬШИ НА ЗАПАДНЫХ ЗЕМЛЯХ УКРАИНЫ В 1920 - 1930-Х ГГ.: СОВРЕМЕННОЕ УКРАИНСКОЕ ВИДЕНИЕ
}

\begin{abstract}
Проанализированы историографические источники, созданные современныли украинскими историками и отражаютщцие состояние изучения государственной политики Второй Речи Посполитой в сфере межнациональных отношений в течение 1920 - 1930-х г2. Показаны приоритетные направления исследований, персонифицирован вклад ученых в изучение научной проблемы, обращено внимание на процесс приращения научных исторических знаний, выделены вопросы, требуюшие дальнейшего рассмотрения.
\end{abstract}

Ключевые слова: историографический источник, национальный вопрос, национальная политика, украинско-польские отношения, государственная ассимиляция.

Лит. 48.

Постановка проблеми. Національне питання було одним із найскладніших у внутрішній політиці Другої Речі Посполитої. Понад 30 \% іï мешканців становили неполяки, з яких половина - українці. Курс польської влади на політичну та культурну інтеграцію національних меншин, передовсім корінного населення Галичини й Західної Волині, а також розвиток національних рухів, як реакція на цю політику, віддавна привертають увагу українських істориків. Ця проблема стала дуже актуальною в останні десятиліття у зв'язку з нагальною необхідністю гармонізації українсько-польських стосунків.

Аналіз досліджень. Національну політику польських урядів у 20 - 30-х рр. ХХ ст. та протидію їй з боку українських національно-патріотичних сил в історіографічному аспекті частково висвітлили М. Кучерепа [48], С. Віднянський [4], Л. Зашкільняк [18], В. Комар [22, 15-18], С. Шумихіна $[47,8-9]$ та деякі інші автори. Однак узагалюнювального дослідження не було написано.

Мета статті - з'ясувати сучасний стан, повноту і достовірність вивчення політики польських урядів щодо національних меншин, передовсім, українців у міжвоєнний період XX ст.

Виклад основного матеріалу. Зміна ідеологічних доктрин, що відбулася в незалежній Україні, відкрила нові можливості для наукової творчості істориків. На основі широкого використання джерел, критичного аналізу заідеологізованої літератури та застосування сучасних методів дослідження почалося наукове переосмислення і вивчення внутрішньої політики відродженої Польської держави, зокрема, польсько-українських відносин. Вагомий внесок у вироблення концепції дослідження означеної проблеми зробив Я. Дашкевич $[12 ; 13 ; 14]$. Вину за польсько-український антагонізм у 20 - 30-х рр. XX ст. він справедливо поклав на більш сильну польську сторону.

Аналіз процесу виникнення та перебігу кризи в польсько-українських взаєминах неминуче ставить питання про ії витоки. Особливість ситуації полягала у тому, як зауважують українські історики, що західні українці опинилися у складі Другої Речі Посполитої всупереч своїй волі, внаслідок воєнних дій, а тому в їхніх очах Польська держава поставала як окупант-загарбник [31, $11 ; 8,202 ; 26,354]$.

Наступний фактор, що спричинився до загострення українсько-польського антагонізму, - це національна політика офіційної Варшави. Як підкреслюють автори досліджень, правлячі кола Польщі розглядали проблему національних меншин насамперед крізь призму безпеки держави, а не як політичну справу. Так, наприклад, М. Швагуляк зазначив, що основні політичні табори міжвоєнної Речі Посполитої ставили собі за мету якнайшвидше інтегрувати Західну Україну до складу Польщі, позбавити тим самим українське населення національної індивідуальності. Різниця між двома найвпливовішими угрупованнями - національною демократією (ендеки) і пілсудчиками - полягала насамперед у методах здійснення цієї мети. Перші, закликаючи до «інкорпорації» українських земель, не спинялися перед насильницькими методами, другі - обстоювали політичні засоби з'єднання згаданих областей з Польщею. Але й ця різниця на практиці була умовною [46, $112 ; 44,5]$.

Своєю чергою, С. Кульчицький виділив два етапи внутрішньої політики Польщі, спрямованої на поглинення «кресів»: державний і етнічний. Державна полонізація, на його думку, означала підпорядкування непольського населення установам, обов'язкам і правилам, які існували в усій 
Польщі, а етнічна була розрахована на тривалий період і передбачала передусім вплив на дітей $[29,282]$.

В історичній літературі наводяться конкретні факти державної асиміляції польських правлячих кіл: ліквідація українських інституцій, котрі забезпечували статус Галичини як окремої адміністративної одиниці, відмова українцям у територіальній автономії, запровадження на етнічних українських землях польської політичної системи, насадження на «східних кресах» колоністів 3 корінних польських земель та ін. Уся система політичних і економічних заходів щодо українського населення підпорядковувалася найважливішій меті - полонізації краю: щоб українське питання або зовсім не існувало б, або не поставало у такій гострій формі $[28,153-155 ; 29,282-285 ; 25$, 11-15; 24, 329-334; 36, 163-164; 37, 79]. Я. Грицак слушно зауважив, що головними жертвами етнічної полонізації стали освітні заклади і церква. Так, за двадцять років польського панування кількість українських шкіл зменшилася з 3662 до 144 [11, 190.]. При цьому автор констатує, що польська влада, на відміну від румунської, яка взагалі позбавляла українців права на розвиток своєї духовності, все-таки залишала «найскромніші можливості для функціонування української мови в шкільництві» $[11,190$.$] .$

У публікаціях звертається увага на той факт, що ставлення польського політикуму до національних меншин, передусім - до українців, було далеко не однозначним. Ю. Макар, скажімо, дійшов такого висновку: якщо народові демократи, праві і центристи у селянському русі, а також християнські демократи вважали, що Польща повинна розбудовуватися як держава однонаціональна, то прихильники Ю. Пілсудського, а за ними соціалісти, ліберали, лівий напрями селянського руху і навіть консерватори висловлювалися за національне рівноправ'я та гарантування прав меншин. Зокрема, соціалісти вимагали автономії для всіх українських земель [33, 482]. На переконання автора, ставлення польської громадськості до українців формувалося переважно ендеками, яких підтримував у своїй більшості католицький клір [33, 482].

Серед причин неприхильного, а то й ворожого ставлення українців до держави та польського суспільства була урядова політика на селі. Як показав у своїй книзі С. Кульчицький, закони про парцеляцію та осадництво використовувалися для колонізації «східних кресів». Хоч політика осадництва тривала весь міжвоєнний період і підтримувалася майже всіма впливовими політичними силами Польщі, ії підсумки не були значними. На кінець 1930-х рр. в Західній Україні налічувалося 47 тисяч осадницьких господарств, але цього було замало, щоб істотно вплинути на національний склад «східних окраїн» [29, 289-290].

Ю. Крамар у докторській дисертації [23] здійснив комплексний аналіз національно-культурної та релігійної політики Польщі на території Волинського воєводства в 1921 - 1939 рр. Зокрема, з'ясував особливості національної, соціальної та конфесійної структури населення Західної Волині, розкрив зміст польської державної політики у сфері міжнаціональних відносин, виявив регіональні особливості впроваджуваної на західноволинських землях політики, простежив форми, методи та засоби ії реалізації щодо місцевого українського, польського, єврейського, німецького, чеського та російського населення, проаналізував освітню і релігійну політику Польщі як інструмент асиміляційного впливу на непольських мешканців краю.

Автор довів, що національна політика польських урядів на території Західної Волині реалізовувалася у межах трьох періодів: 1) 1921 - 1925 рр. - пріоритет доктрини польських національно-демократичних сил, який передбачав лише мононаціональний характер культурного життя, національну асиміляцію непольських народів; 2) у 1926 - 1934 рр. відбувається модифікація програмних засад польської національної політики, офіційне оголошення режимом «санації» політики державної асиміляції національних меншин. Програма пілсудчиків у національному питанні мала на меті замінити скомпрометовану ендецьку політику примусової денаціоналізації нацменшин федералістською програмою державної асиміляції; 3) протягом 1935 - 1939 рр. у національній політиці «санації» відбувся різкий поворот управо: утвердилася нова концепція, відома як «політика зміцнення польськості Речі Посполитої» або «політика національно-державної асиміляції» нацменшин. Зростання ролі військових у суспільно-політичному житті держави, пропаганда політичними організаціями пілсудчиків нових форм польського тоталітаризму поставили на порядок денний радикальні концепції розв'язання національного питання [23, 380-381].

Як з'ясував Ю. Крамар, державно-церковна політика Другої Речі Посполитої на західноволинських землях еволюціонувала під впливом боротьби політичних сил у самій державі та активізації національно-церковного руху на цих теренах. У період 1918 - 1926 рр. спостерігалася тенденція на конфесійну асиміляцію українського православного населення, його найтіснішу інтеграцію 3 
польською нацією й Римо-католицькою церквою. Така політика активізувала український національно-церковний рух на Волині, який займав опозиційне становище і щодо церковної влади, котра залишалася на промосковських позиціях, і щодо держави, яка прагнула використати церкву як інструмент впливу на місцеве українське населення. Після травневого перевороту 1926 р. пропонований пілсудчиками курс в українському питанні, серед іншого, передбачав толерантнішу релігійну політику, яка, на думку пілсудчиків, дала б змогу прив'язати українців до платформи польської державності і сприяла б їх відверненню від боротьби за національне визволення. Однак упродовж 1935 - 1939 рр., коли відбувався поступовий відхід від ліберальних проектів розв'язання українського питання, пріоритетом державно-церковної політики стала полонізація Православної церкви в Польщі та їі підпорядкування інтересам держави [23, 387].

Польську політику національної і релігійної асиміляції українців, стан православ'я в Польщі, динаміку українізації Православної церкви розглянули й інші дослідники, як-от: В. Борщевич, Б. Савчук, Н. Стоколос, М. Кучерепа та В. Оніщук $[1 ; 2 ; 32 ; 38 ; 40]$.

Пом'якшення польської політики в українському питанні стала причиною появи т. зв. «волинського експерименту», реалізатором якого у 1928 - 1938 рр. був воєвода Г. Юзевський. У числі перших це питання почав вивчати М. Кучерепа. В одній зі своїх публікацій він резонно констатував, що офіційна Варшава, розробляючи політичну лінію щодо українців, намагалася поглибити регіональні особливості і розчленувати на окремі частини єдиний український народ. Саме на це і були спрямовані заходи нового адміністратора Волині [30, 112-117]. Назагал, висновував автор, проект Г. Юзевського зазнав краху. Політика польсько-українського співжиття на Волині не відбулася. Цьому зашкодили радикальні як польські, так і українські політичні сили, які своїми діями компрометували «волинський експеримент» воєводи. Значною мірою це стало генезою польсько-українського збройного протистояння на Волині в роки Другої світової війни [30, 131].

Викликає інтерес ступінь дослідженості проблеми розвитку кооперації на Волині у контексті політичної лінії Г. Юзевського. Так, Т. Вісина і В. Вісин показали, що після прийняття нового кооперативного закону Польщі (1934) відбулася реорганізація кооперативної мережі усієї держави, внаслідок чого найбільше потерпіла українська кооперація на Волині. Кооперативи, що належали до Ревізійного союзу українських кооперативів, було насильно від нього відірвано і приєднано до трьох союзів, що діяли на терені воєводства, в основному до українсько-польського «Гурту» та польського Союзу рільничих і зарібково-господарських кооперативів. Якщо до середини 1937 р. кооперативи Волині ще виказували якийсь поступ, то з кінця 1937 р. наступив застій. Під кінець 30-х рр. були ще деякі штучні проекти створення Волинського союзу кооперативів, проте до здійснення цих планів так і не дійшло. Український кооперативний рух у краї був по суті ліквідований, розчинений у польських кооперативних центрах $[6,13 ; 5,244-247]$.

Заслугою В. Комара є показ місця і ролі українського питання в прометеївському русі та політиці прометеїзму Польщі [22, 190-209, 224-239, 267-296; 21]. Як з'ясував автор, здійснення прометеївських планів пілсудчиків передбачало перетворення західноукраїнських земель на «П' $\epsilon$ монт» національно-визвольних змагань усіх українців і його подальше використання в інтересах Польської держави (насамперед ішлося про переорієнтацію вектора українського націоналізму 3 антипольського на антирадянський напрям). Саме у цій площині висвітлено спробу нормалізації українсько-польських взаємин у 1930-х рр. і політичний експеримент Г. Юзевського на Волині. В. Комар довів, що державна асиміляція галицьких українців мала відбуватися у рамках нормалізаційної угоди з УНДО. Подібною була тактика волинського воєводи, який шляхом забезпечення мінімальних потреб українців намагався усунути деструктивний елемент конфлікту між двома народами й виховати лояльних громадян держави. Проте, констатував автор, спроби державної асиміляції українців як складової концепції прометеїзму Польщі були приречені на невдачу. I не тільки через позицію національно свідомого українства, а й суперечливість політики Ю. Пілсудського в українському питанні. Пілсудчики не помічали органічної єдності між Галичиною та Наддніпрянською Україною, яка, до того ж, вже була зафіксована юридично в Акті злуки від 22 січня 1919 р. Ю. Пілсудський і його соратники нібито підтримували незалежність України над Дніпром, яка мала стати бар'єром на шляху російської експансії, а з іншого боку, як і більшість поляків, вважали Галичину невід'ємною частиною Польської республіки $[22,301 ; 21,168]$.

Важливим є питання реакції української громадськості на перехід польського уряду до силових методів управління. Чимало його аспектів порушено у працях М. Кугутяка, С. Кульчицького, М. Швагуляка, I. Соляра. Йдеться, зокрема, про те, що натиск властей спричинив поділ серед українського політикуму. Ці процеси захопили і найвпливовішу українську партію - Україн- 
ське національно-демократичне об’єднання (УНДО). У ній активізувалися прихильники пошуку порозуміння з владою. У лютому 1931 р. представники ЦК УНДО вели переговори з діячами польського правлячого табору, в ході яких порушували справу врегулювання відносин 3 державою. Ці політичні тенденції серед націонал-лібералів перегукувалися з настроями, що панували в західноукраїнських консервативних колах. Але вони викликали неприхильну реакцію в українському суспільстві [44, 30-32].

Історики приділили багато уваги політиці «нормалізації» 1935 р., зокрема з'ясовано причини і приводи чергового українсько-польського «замирення», мотиви, якими керувалися обидві сторони при досягненні порозуміння, тощо [17; 11, 199-200; 35, 517-530]. Дослідники одностайні у тому, що «нормалізація» була тактичним компромісом, а не принциповою угодою, вона не користувалася популярністю як у польському, так і українському таборах. Серед чинників, які привели до краху «нормалізації» називаються й такі: угода була укладена на словах, а не на письмі; отже, іiі майбутнє залежало винятково від доброї волі обидвох сторін; хибне уявлення польських політиків про неготовність і незрілість української спільноти до самостійного державного творення; місцеві чиновники керувалися не стільки інструкціями з Варшави, скільки власними інтересами.

Однією з причин кризи польсько-українських відносин напередодні Другої світової війни, як правильно зауважив М. Швагуляк, «була нездатність українського політикуму випрацювати платформу, що відповідала б умовам напівавторитарного режиму в Польщі та передбачала б і враховувала би прийдешні міжнародні катаклізми та їх можливий вплив на долю українства» [45, 492].

Дослідивши зовнішньополітичні орієнтири національно-державницьких партій Західної України, I. Соляр ствердив, що націонал-демократи балансували між ідеєю негації Польщі і прагненням здобути національно-територіальну автономію у складі Польської держави. Лише наприкінці 1930-х рр. вони усвідомили загрозу повного відсунення українського чинника від впливу не тільки на внутрішню і зовнішню політику Другої Речі Посполитої, а й на українське організоване життя в Галичині, небезпеку для українців стати лише національною меншиною в Польщі [39, 26].

В оригінальний спосіб розглянув особливості суспільно-політичної ситуації в західному регіоні України I. Федик. Він акцентував на ролі психологічного фактора - ставлення провідних українських політичних сил до Польщі, - який «спрацьовував на рівні національної свідомості, сконцентровуючи політичну енергію партійної еліти та широкого українського загалу в єдину силу, спрямовану проти окупаційного режиму» $[42,61]$. Тобто, цей чинник був рушієм політичної боротьби в тогочасному польському суспільстві, він виконував не тільки націєзахисну, а й об'єднувальну функції для українських політичних середовищ. Автор небезпідставно стверджує, що негація націонал-демократів до Польської держави зазнавала змін, інколи модифікувалася у позитиви, а це, своєю чергою, впливало на політичну тактику - наприклад, призводило до пошуку компромісів із польською владою [42, 65].

Предметом підвищеної уваги істориків стала українська саботажна акція 1930 р. в Галичині, що, згідно з офіційною версією польського уряду, спричинила різке загострення становища, змусивши власті вдатися до контрзаходів з метою наведення порядку в краї.

Першопричини вибуху саботажної кампанії окремі історики (С. Кульчицький, Л. Зашкільняк і М. Крикун) вбачають у загострені соціальної напруги, особливо на селі, у період великої депреciї 1929 - 1933 рр. На їхню думку, соціальні суперечності, що набули форми міжнаціональних, активізували діяльність українських політичних партій і рухів, а надто ліво- та праворадикальних сил $[29,308 ; 16,474]$. Вплив економічної кризи 1929 р. на загострення ситуації в Західній Україні відзначили й інші дослідники. Автор спеціальної розвідки М. Швагуляк, аналізуючи цей аспект питання, наголосив на загостренні внутрішньополітичної ситуації в країні, яку спричинив конфлікт між пілсудчиками та опозицією, а також на ревізіоністських тенденціях у зовнішній політиці Німеччини. «Не випадково, - писав він, - у розпал антипольської кампанії у Німеччині (літо 1930 р.) над Західною Україною піднялася заграва пожеж» [46, 114-115].

Неоднозначними $є$ оцінки характеру саботажної акції. Так, наприклад, I. Васюта розглянув iii винятково як «селянський» або «національно-селянський» рух. Автор не взяв на віру інформацію, що міститься в документах органів державної безпеки Польщі, а надав перевагу концепції, що домінувала у попередній історіографічний період. Тобто, саботажна кампанія висвітлена ним як революційний рух селян і сільськогосподарських робітників проти польських гнобителів. Щоправда, на відміну від радянських істориків, учений не відкинув роль українських націоналістичних сил в антипольській акції $[3,50-51]$. 
Проте в історичній літературі переважає думка, що організувала цей рух УВО-ОУН суто на національній основі $[20,45 ; 11,198]$. М. Швагуляк виокремив три категорії підпалів та інших акцій у Західній Україні влітку і восени 1930 р.: найменшу чисельно групу становили підпали будівель польськими власниками (з метою отримання компенсацій); певна кількість організованих, а головно стихійних, акцій припадала на долю прокомуністично налаштованих селян; основна частини саботажів була здійснена УВО $[44,13]$.

Центральним питанням проблеми, яке досі найбільше привертає увагу науковців, $є$ так звана «пацифікація»- урядова репресивна акція проти українського населення Галичини восени 1930 р. Усі автори сходяться на тому, що «пацифікація» була безпосередньо пов'язана з українською саботажною кампанією, тобто була реакцією влади на неї. В окремих дослідженнях каральна акція польської влади розглядається у контексті загальнополітичної кризи в Польщі, як складова частина придушення Пілсудським будь-яких вияві опозиції [44, 16-25].

Українські історики, висвітлюючи хід «пацифікації», відзначають безоглядність спеціальних поліційних відділів у діях супроти українського населення. Часто ці дії виходили за межі закону. Таким протиправним явищем було застосування методу колективної відповідальності щодо сотень українських сільських громад у трьох воєводствах колишньої Східної Галичини. Це дало підставу вченим характеризувати всю «пацифікаційну» операцію як «брутальну», основна мета якої полягала в тому, щоб залякати українське населення, зламати опір українців асиміляторськими зусиллями держави [16, 475; 7, 221-222].

Активно дослідуючи природу українсько-польського протистояння 1920 - 1930-х pp. ХХ ст., українські історики практично одностайні у висновку, що саме польська сторона першою повинна нести відповідальність за його конфронтаційний характер і наслідки конфлікту, позаяк Польща здебільшого ігнорувала міжнародні зобов'язання щодо забезпечення прав і свобод населення Західної України, не враховувала національних та соціальних інтересів української меншості, не спромоглася, зокрема, надати хоча б елементарної автономії південно-східним воєводствам. Оцінюючи характер українсько-польських відносин у міжвоєнні роки, відомий львівський історик Я. Дашкевич, наприклад, переконаний: «Наївно вважати, що їхній характер залежав від підкореного українського народу. Такі події XX ст., як окупація Східної Галичини, недотримання ухвал Рад послів про автономію Галичини, економічна експлуатація в межах Польщі «Б», культурна й освітня дискримінація, протиправні дії типу пацифікації, табору в Березі Картузькій, руйнування церков на Холмщині, дискримінація у парцеляційній політиці, стимулювання осадництва, намагання відділити від єдиної української нації лемків, гуцулів, «старорусинів», ходачкову шляхту, глузування з національної гідності українців - усе це разом, та ще чимало іншого могло призвести до того, до чого й призвело: до різкого загострення польсько-українських стосунків, які вилилися в трагічні події 1942 - 1944 рр.» [14, 26-27]. Водночас, як зазначають українські дослідники, більшість українських політичних партій та громадських організацій засудили терор ОУН проти польських властей на початку 1930-х рр. і схилилися до порозуміння з Польською державою на засадах впровадження культурно-національної автономії у Галичині та Волині. I якби польські власті з належною відповідальністю поставилися до справи «нормалізації» 1935 р., то, на думку Л. Зашкільняка, дальший перебіг українсько-польських взаємин мав би цілком відмінне спрямування $[15,454]$.

Варто відзначити ще одну важливу деталь. Сучасні українські історики, на відміну від радянських, будують свої висновки не тільки на негативізмі. Робиться спроба відшукати і позитивні моменти політики Польщі щодо українців у міжвоєнний період. Дослідники констатують, що українське населення у Польщі перебувало у вигіднішому становищі, ніж українці та поляки на території більшовицької України. На щастя, його не торкнулися штучні голодомори, колективізація і націоналізація, сталінські депортації і репресії. Відроджена Польська держава була, з одного боку авторитарною державою, а з іншого - парламентською і плюралістичною за партійним представництвом. Такий державний статус Другої Речі Посполитої надавав українцям можливості легітимним чином виборювати свої права, дозволяв їм, хоча й в обмежених формах, розвивати культуру, національну тотожність, колективне та релігійне життя [31, 28; 8, 230].

Різні аспекти єврейського питання у міжвоєнній Польщі вивчали Я. Хонігсман, М. Гон, А. Подольський, С. Качараба, I. Федик [9; 10; 19, 256-315; 34; 41; 43] та інші. Автори сходяться на тому, що більшість єврейського населення, яке проживало в Західній Україні, демонструвало свою лояльність до Другої Речі Посполитої. Незважаючи на політику державного антисемітизму, яку відкрито проводили польські уряди у 1920 - 1930-х рр., національне життя євреїв не було 
припинене чи взагалі заборонене, а навпаки досить бурхливо розвивалося. Крім великої кількості партій і громадських організацій, в Польщі діяли сотні релігійних, гуманітарних і різного роду допомогових організацій, шкіл і релігійних установ. Свреї мали досить поважне представництво в польському парламенті, до політичних та соціальних середовищ входили багато банкірів і фінансистів, які спонсорували значні суми на єврейське політичне, національне та культурне життя, а також на виїзд в історичну Батьківщину - Палестину. За словами А. Подольського, «це був своєрідний виклик чи опір польського, галицького єврейства державному антисемітизмові» $[34,10]$. Назагал, попри всі негаразди, соціально-культурний розвиток єврейської меншини цього регіону істотно відрізнявся від стану євреїв, які мешкали на українських теренах у складі СРСР.

Висновки. Отже, сьогодні вже можна говорити про наявність значної кількості досліджень, в яких йдеться про національну політику Польщі на західних землях України у 1920 - 1930-х рр. Характерно, що історики в основному вивчають стан українсько-польських взаємин, зосередивши при цьому увагу на таких питаннях, як джерела і причини загострення цих взаємин; ставлення польських політичних сил до української меншини; шляхи і методи асиміляції українців; українська саботажна акція, її місце і роль в українсько-польській конфронтації; польська урядова «пацифікація», її цілі та характер; позиція українських політичних сил щодо нового курсу Ю. Пілсудського; політика «нормалізації» та причини іiї краху; «волинський експеримент» воєводи Г. Юзевського, Західна Україна в орбіті польського прометеїзму. Вагомими є здобутки вчених у вивченні проблеми відносин польської влади з єврейською меншиною.

Однак аналізована проблема потребує подальшого вивчення. Зокрема, серед історичних досліджень останніх десятиліть мало публікацій, що розкривають спробу порозуміння поляків $\mathrm{i}$ українців, пошуки шляхів співпраці обох народів. Варто приділити більше уваги показу етнонаціональної політики Польщі крізь призму їі зовнішньополітичного курсу. Перспективним напрямом дослідження може стати питання про реакцію світової громадськості на загострення польсько-українських стосунків у міжвоєнний період XX ст. Можна сподіватися, що надалі все більшої ваги набиратимуть українські студії, присвячені політиці офіційної Варшави щодо німців, чехів, вірменів та деяких інших національних меншин, що мешкали на теренах західних земель України у 1920 - 1930-х рр.

\section{СПИСОК ВИКОРИСТАНИХ ДЖЕРЕЛ І ЛІТЕРАТУРИ}

1. Борщевич В. Українське церковне відродження на Волині $(20-40-\mathrm{i}$ рр. ХХ ст.): Монографія / В. Борщевич. - Луцьк: Ред.-вид. відділ «Вежа» Волинського державного університету ім. Лесі Українки, 2000. $-254 \mathrm{c}$.

2. Борщевич В. Т. Волинське духовенство у XX ст.: ідентичність, статус, еволюція: монографія / В. Т. Борщевич. - Луцьк: РВВ Волин. нац. ун-ту ім. Лесі Українки, 2010. - 584 с.

3. Васюта І. К. Національно-визвольний рух у Західній Україні $(1918$ - 1939 рр.) / І. К. Васюта // Укр. іст. журн. - 2001. - № 6. - С. 35-64.

4. Віднянський С. В. Українське питання в міжвоєнній Польщі: основні проблеми й напрямки наукових досліджень у сучасній вітчизняній історичній науці / С. В. Віднянський // Укр. іст. журн. - 2003. - № 2. - C. 39-55.

5. Вісин В. «Свій до свого, по своє»: кооперативний рух на Волині й Галичині у міжвоєнний період / В. Вісин // Проект «Україна». Галичина та Волинь у складі міжвоєнної Польщі. - Харків: Фоліо, 2017. C. $226-247$.

6. Вісина Т. М. Український кооперативний рух у Волинському воєводстві в 20-30-х роках XX ст.: автореф. дис. ... канд. істор. наук: спец. 07.00 .01 - історія України / Т. М. Вісина. - Львів, 2002. - 18 с.

7. Гаврилів I. Західна Україна у 1921 - 1941 роках: нарис історії боротьби за державність: монографія / І. Гаврилів. - Львів: Видавництво Львівської політехніки, 2012. - 472 с.

8. Гетьманчук М. П. «Українське питання» в радянсько-польських відносинах 1920 - 1939 рр. / М. П. Гетьманчук. - Львів: Світ, 1998. - 428 с.

9. Гон М. Єврейське питання в Західній Україні напередодні Другої Світової війни (за матеріалами громадсько-політичної періодики краю) / М. Гон // Голокост і сучасність. Студії в Україні і світі. - 2005. № 1. - C. 9-27.

10. Гон М. Із кривдою на самоті. Українсько-єврейські взаємини на західноукраїнських землях у складі Польщі (1935 - 1939): монографія / М. Гон. - Рівне: Волинські обереги, 2005. - 192 с.

11. Грицак Я. Нарис історії України: формування модерної української нації XIX - XX ст. / Я. Грицак. - К.: Генеза, 2000. - 360 с. 
12. Дашкевич Я. Перегук віків: три погляди на минуле і сучасне України / Я. Дашкевич // Україна: наука і культура. Вип. 26-27. - К., 1993. - С. 44-78.

13. Дашкевич Я. Східна Галичина: етнічні відносини, національні міфи та менталітет / Я. Дашкевич // Україна в минулому. - К. - Львів: Інститут української археографії, 1994. - Вип. 6. - С. 78-93.

14. Дашкевич Я. Шляхи подолання упереджень (Перешкоди нормалізації польсько-українських стосунків) / Я. Дашкевич // Україна - Польща. Історична спадщина і суспільна свідомість. - К., 1993. - Вип. 1. - С. 23-29.

15. Зашкільняк Л. Генеза і наслідки українсько-польської нормалізації / Л. Зашкільняк // Polska i Ukraina: Sojusz 1920 roku i jego następstwa. - Toruc, 1997. - S. 431-454.

16. Зашкільняк Л. Історія Польщі. Від найдавніших часів до наших днів / Л. Зашкільняк, М. Крикун. Львів: Львівський національний університет імені Івана Франка, 2002. - 752 с.

17. Зашкільняк Л. Українсько-польське порозуміння 1935 р. (за матеріалами архіву Я. С. Лося) / Л. Зашкільняк // Проблеми слов'янознавства. Міжвід. наук. зб. - Львів, 1996. - Вип. 48. - С. 62-72.

18. Зашкільняк Л. Україна і Польща в XX столітті: від конфліктів до порозуміння / Л. Зашкільняк // Україна: культурна спадщина, національна свідомість, державність. Вип. 17: Українсько-польсько-білоруське сусідство: XX століття / НАН України, Ін-т українознавства ім. І. Крип'якевича. - Львів, 2008. C. $3-18$.

19. Качараба С. П. Еміграція з Західної України 1919 - 1939 / С. П. Качараба. - Львів: Львівський національний університет імені Івана Франка, 2003. - 416 с.

20. Кентій А. В. Нариси історії Організації українських націоналістів (1929 - 1941 рр.) / А. В. Кентій. К.: Інститут історії України НАН України, 1998. - 201 с.

21. Комар В. В орбіті польського прометеїзму / В. Комар // Проект «Україна». Галичина та Волинь у складі міжвоєнної Польщі. - Харків: Фоліо, 2017. - С. 145-168.

22. Комар В. Л. Концепція прометеїзму в політиці Польщі (1921 - 1939 рр.) / В. Л. Комар. - Івано-Франківськ: Місто-НВ, 2011. - 360 с.

23. Крамар Ю. В. Національно-культурна та релігійна політика урядів Польщі на Волині (1921 1939 рр.): дис. ... докт. іст. наук: спец. 07.00 .02 - всесвітня історія [Електронний ресурс] / Ю. В. Крамар. Львів, 2015. - 536 с. - Режим доступу: http://www.lnu.edu.ua/wp-content/uploads/2015/12/dis_kramar.pdf

24. Крамар Ю. Польська політика асиміляції українців Волині у 1928 - 1938 рр. / Ю. Крамар // Дрогобицький краєзнавчий збірник. Спецвипуск. - Дрогобич, 2002. - С. 326-338.

25. Крамар Ю. В. Політика державної асиміляції на Волині (1928 - 1938 роки): автореф. дис. ... канд. істор. наук: спец. 07.00.02 - всесвітня історія / Ю. В. Крамар. - Львів, 1998. - 18 с.

26. Красівський О. Галичина у першій чверті XX ст. Проблеми польсько-українських стосунків / О. Красівський. - Львів: Вид-во ЛФУАДУ, 2000. - 414 с.

27. Красівський О. Східна Галичина і Польща в 1918 - 1923. Проблеми взаємовідносин / О. Красівський. - К.: Вид-во УАДУ, 1998. - 304 с.

28. Кугутяк М. Галичина: сторінки історії. Нарис суспільно-політичного руху (XIX ст. - 1939 р.) / М. Кугутяк. - Івано-Франківськ: Б.в., 1993. - 204 с.

29. Кульчицький С. В. Україна між двома війна $(1921$ - 1939 рр.) / С. В. Кульчицький. - К.: Видавничий Дім «Альтернативи», 1999. - 336 с. - (Україна крізь віки. - Т. 11).

30. Кучерепа М. «Волинський експеримент» воєводи Г. Юзевського / М. Кучерепа // Проект «Україна». Галичина та Волинь у складі міжвоєнної Польщі. - Харків: Фоліо, 2017. - С. 111-131.

31. Кучерепа М. Національна політика Другої Речі Посполитої щодо українців (1919 - 1939 рр.) / М. Кучерепа // Матеріали II міжнародного семінару істориків «Українсько-польські відносини в 1918 1947 рр.». - Варшава, 22-24 травня 1997 р. - 1998. - С. 11-28.

32. Кучерепа М. Православ'я на Волині (1921 - 1939 рр.) / М. Кучерепа, В. Оніщук // Збірник навчально-методичних матеріалів і наукових статей історичного факультету. - Луцьк: Ред.-вид. відділ «Вежа» Волинського державного університету ім. Лесі Українки, 1998. - № 3. - С. $73-77$.

33. Макар Ю. Становище українців у міжвоєнній Польщі / Ю. Макар // Четвертий міжнародний конгрес україністів. Доповіді та повідомлення. Історія. Частина 2: ХХ ст. - Одеса - Київ - Львів, 1989. - С. 480-486.

34. Подольський А. Ю. Уроки минулого: Історія Голокосту в Україні: Навч. посібник / А. Ю. Подольський. - К.: ТОВ «Спринт-Сервіс», 2016. - 104 с.

35. Політична історія України. ХХ століття: У 6-ти т. / [Редкол.: І. Ф. Курас (голова) та ін.]. - К.: Генеза, 2002. - Т. 5: Українці за межами УРСР (1918 - 1940) [Керівник тому В. П. Трощинський]. - К., 2003. - 720 с.

36. Руда О. Державна політика Другої Речі Посполитої в національній сфері у 1918 - 1926 роках / О. Руда // Проблеми гуманітарних наук: збірник наукових праць Дрогобицького державного педагогічного університету імені Івана Франка. Серія «Історія». - Дрогобич, 2015. - Випуск 36. - С. 160-174. 
37. Руда О. В. Національна політика Польської держави у 1926 - 1939 роках / О. В. Руда // Наукові праці історичного факультету Запорізького національного університету. - Запоріжжя, 2015. - Вип. 44. Том 2.- C. $76-80$.

38. Савчук Б. За Українську церкву. Національно-церковний рух на Волині у 20 - 30-ті pp. XX ст. / Б. Савчук. - Івано-Франківськ: Лілея-НВ, 1997. - 116 с.

39. Соляр І. Я. Зовнішні орієнтації національно-державницьких партій Західної України (1923 - 1939): автореф. дис. ... докт. істор. наук: спец. 07.00 .01 - історія України / І. Я. Соляр. - Івано-Франківськ, 2012. $34 \mathrm{c}$.

40. Стоколос Н. Г. Конфесійно-етнічна трансформація в Україні (XIX - перша половина XX ст.): Монографія / Н. Г. Стоколос. - Рівне: РІС КСУ - ППФ «Ліста-М», 2003. - 480 с.

41. Федик І. Національна політика міжвоєнної Польщі в Галичині: єврейський контекст (на прикладі діяльності правоохоронних органів) / І. Федик // Наукові зошити історичного факультету Львівського університету. - 2012 - 2013. - Випуск 13-14. - С. 589-595.

42. Федик І. УНДО, ОУН: ставлення до Польщі / І. Федик. - Львів: Б. в., 1998. - 80 с.

43. Хонигсман Я. Катастрофа еврейства Западной Украины. Евреи Восточной Галиции, Западной Волыни, Буковины и Закарпатья в 1933 - 1945 годах / Я. Хонигсман. - Львов: Б. и., 1998. - 352 с.

44. Швагуляк М. «Пацифікація». Польська репресивна акція у Галичині 1930 року і українська суспільність / М. Швагуляк. - Львів: Інститут українознавства ім. І. Крип’якевича НАН України, 1993. - 52 с.

45. Швагуляк М. Львів: від столиці Західноукраїнської держави до політичного центру українців Галичини (1918 - 1939 рр.) / М. Швагуляк // Львів: місто - суспільство - культура: Збірник наукових праць. Т. 3. Спеціальний випуск Вісника Львівського університету. Серія історична. - Львів, 1999. - С. 469-492.

46. Швагуляк М. Суспільно-політична ситуація у Західній Україні на початку 30-х років XX ст. / М. Швагуляк // Записки Наукового Товариства імені Шевченка. - Том ССХХІІ. Праці історико-філософської секції. - Львів: НТШ, 1991. - С. 111-145.

47. Шумихіна С. О. Українська історіографія міжвоєнної Польщі (1918 - 2012 рр.): автореф. дис. ... канд. істор. наук: спец. 07.00.06 - історіографія, джерелознавство та спеціальні історичні дисципліни / С. О. Шумихіна. - К., 2013. - 16 с.

48. Kuczerepa M. Stosunki ukraińsko-polskie w II Rzeczypospolitej we współczesnej historiografii ukraińskiej / M. Kuczerepa // Historycy Polscy i Ukraińscy wobec problemów XX wieku. - Kraków, 2000. - S. 146-165.

\section{SPYSOK VYKORYSTANYKh DZhEREL I LITERATURY}

1. Borshchevych V. Ukrainske tserkovne vidrodzhennia na Volyni $(20-40$-i rr. XX st.): Monohrafiia / V. Borshchevych. - Lutsk: Red.-vyd. viddil «Vezha» Volynskoho derzhavnoho universytetu im. Lesi Ukrainky, 2000. $-254 \mathrm{~s}$.

2. Borshchevych V. T. Volynske dukhovenstvo u XX st.: identychnist, status, evoliutsiia: monohrafiia / V. T. Borshchevych. - Lutsk: RVV Volyn. nats. Un-tu im. Lesi Ukrainky, 2010. - 584 s.

3. Vasiuta I. K. Natsionalno-vyzvolnyi rukh u Zakhidnii Ukraini (1918 - 1939 rr.) / I. K. Vasiuta // Ukr. ist. zhurn. - 2001. - № 6. - S. 35-64.

4. Vidnianskyi S. V. Ukrainske pytannia v mizhvoiennii Polshchi: osnovni problemy y napriamky naukovykh doslidzhen u suchasnii vitchyznianii istorychnii nautsi / S. V. Vidnianskyi // Ukr. ist. zhurn. - 2003. - № 2. - S. 39-55.

5. Visyn V. «Svii do svoho, po svoie»: kooperatyvnyi rukh na Volyni y Halychyni u mizhvoiennyi period / V. Visyn // Proekt «Ukraina». Halychyna ta Volyn u skladi mizhvoiennoi Polshchi. - Kharkiv: Folio, 2017. S. 226-247.

6. Visyna T. M. Ukrainskyi kooperatyvnyi rukh u Volynskomu voievodstvi v 20 - 30-kh rokakh XX st.: avtoref. dys. ... kand. istor. nauk: spets. 07.00 .01 - istoriia Ukrainy / T. M. Visyna. - Lviv, 2002. - 18 s.

7. Havryliv I. Zakhidna Ukraina u 1921-1941 rokakh: narys istorii borotby za derzhavnist: monohrafiia / I. Havryliv. - Lviv: Vydavnytstvo Lvivskoi politekhniky, 2012. - $472 \mathrm{~s}$.

8. Hetmanchuk M. P. «Ukrainske pytannia» v radiansko-polskykh vidnosynakh 1920 - 1939 rr. / M. P. Hetmanchuk - Lviv: Svit, 1998. - 428 s.

9. Hon M. Yevreiske pytannia v Zakhidnii Ukraini naperedodni Druhoi Svitovoi viiny (za materialamy hromadsko-politychnoi periodyky kraiu) / M. Hon // Holokost i suchasnist. Studii v Ukraini i sviti. - 2005. - № 1. S. 9-27.

10. Hon M. Iz kryvdoiu na samoti. Ukrainsko-yevreiski vzaiemyny na zakhidnoukrainskykh zemliakh u skladi Polshchi (1935 - 1939): monohrafiia / M. Hon. - Rivne: Volynski oberehy, 2005. - $192 \mathrm{~s}$.

11. Hrytsak Ya. Narys istorii Ukrainy: formuvannia modernoi ukrainskoi natsii XIX - XX st. / Ya. Hrytsak. K.: Heneza, 2000. - $360 \mathrm{~s}$. 
12. Dashkevych Ya. Perehuk vikiv: try pohliady na mynule i suchasne Ukrainy / Ya. Dashkevych // Ukraina: nauka i kultura. - K., 1993. - Vyp. 26-27. - S. 44-78.

13. Dashkevych Ya. Skhidna Halychyna: etnichni vidnosyny, natsionalni mify ta mentalitet / Ya. Dashkevych // Ukraina v mynulomu. - K. - Lviv: Instytut ukrainskoi arkheohrafii, 1994. - Vyp. 6. - S. 78-93.

14. Dashkevych Ya. Shliakhy podolannia uperedzhen (Pereshkody normalizatsii polsko-ukrainskykh stosunkiv) / Ya. Dashkevych // Ukraina - Polshcha. Istorychna spadshchyna i suspilna svidomist. - K., 1993. Vyp. 1. - S. 23-29.

15. Zashkilniak L. Heneza i naslidky ukrainsko-polskoi normalizatsii / L. Zashkilniak // Polska i Ukraina: Sojusz 1920 roku i jego nastкpstwa. - Toruc, 1997. - S. 431-454.

16. Zashkilniak L. Istoriia Polshchi. Vid naidavnishykh chasiv do nashykh dniv / L. Zashkilniak, M. Krykun. Lviv: Lvivskyi natsionalnyi universytet imeni Ivana Franka, 2002. - 752 s.

17. Zashkilniak L. Ukrainsko-polske porozuminnia 1935 r. (za materialamy arkhivu Ya. S. Losia) / L. Zashkilniak // Problemy slovianoznavstva. Mizhvid. nauk. zb. - Lviv, 1996. - Vyp. 48. - S. 62-72.

18. Zashkilniak L. Ukraina i Polshcha v XX stolitti: vid konfliktiv do porozuminnia / L. Zashkilniak // Ukraina: kulturna spadshchyna, natsionalna svidomist, derzhavnist. Vyp. 17: Ukrainsko-polsko-biloruske susidstvo: XX stolittia / NAN Ukrainy, In-t ukrainoznavstva im. I. Krypiakevycha. - Lviv, 2008. - S. 3-18.

19. Kacharaba S. P. Emihratsiia z Zakhidnoi Ukrainy 1919 - 1939 / S. P. Kacharaba. - Lviv: Lvivskyi natsionalnyi universytet imeni Ivana Franka, 2003. - 416 s.

20. Kentii A. V. Narysy istorii Orhanizatsii ukrainskykh natsionalistiv $(1929-1941$ rr.) / A. V. Kentii. - K.: Instytut istorii Ukrainy NAN Ukrainy, 1998. - $201 \mathrm{~s}$.

21. Komar V. V orbiti polskoho prometeizmu / V. Komar // Proekt «Ukraina». Halychyna ta Volyn u skladi mizhvoiennoi Polshchi. - Kharkiv: Folio, 2017. - S. 145-168.

22. Komar V. L. Kontseptsiia prometeizmu v politytsi Polshchi $(1921$ - 1939 rr.) / V. L. Komar. - Ivano-Frankivsk: Misto-NV, 2011. - 360 s.

23. Kramar Yu. V. Natsionalno-kulturna ta relihiina polityka uriadiv Polshchi na Volyni (1921 - 1939 rr.): dys. ... dokt. ist. nauk: spets. 07.00.02 - vsesvitnia istoriia [Elektronnyi resurs] / Yu. V. Kramar. - Lviv, 2015. - 536 s. Rezhym dostupu: http://www.Inu.edu.ua/wp-content/uploads/2015/12/dis_kramar.pdf

24. Kramar Yu. Polska polityka asymiliatsii ukraintsiv Volyni u 1928 - 1938 rr. / Yu. Kramar // Drohobytskyi kraieznavchyi zbirnyk. Spetsvypusk. - Drohobych, 2002. - S. 326-338.

25. Kramar Yu. V. Polityka derzhavnoi asymiliatsii na Volyni (1928 - 1938 roky): avtoref. dys. ... kand. istor. nauk: spets. 07.00.02 - vsesvitnia istoriia / Yu. V. Kramar. - Lviv, 1998. - 18 s.

26. Krasivskyi O. Halychyna u pershii chverti XX st. Problemy polsko-ukrainskykh stosunkiv / O. Krasivskyi. - Lviv: Vyd-vo LFUADU, 2000. - 414 s.

27. Krasivskyi O. Skhidna Halychyna i Polshcha v 1918 - 1923. Problemy vzaiemovidnosyn / O. Krasivskyi. - K.: Vyd-vo UADU, 1998. - 304 s.

28. Kuhutiak M. Halychyna: storinky istorii. Narys suspilno-politychnoho rukhu (XIX st. - 1939 r.) / M. Kuhutiak. - Ivano-Frankivsk: B.v., 1993. - 204 s.

29. Kulchytskyi S. V. Ukraina mizh dvoma viinamy (1921 - 1939 rr.) / S. V. Kulchytskyi. - K.: Vydavnychyi Dim «Alternatyvy», 1999. - 336 s. - (Ukraina kriz viky. - T. 11).

30. Kucherepa M. «Volynskyi eksperyment» voievody H. Yuzevskoho / M. Kucherepa // Proekt «Ukraina». Halychyna ta Volyn u skladi mizhvoiennoi Polshchi. - Kharkiv: Folio, 2017. - S. 111-131.

31. Kucherepa M. Natsionalna polityka Druhoi Rechi Pospolytoi shchodo ukraintsiv (1919 - 1939 rr.) / M. Kucherepa // Materialy II mizhnarodnoho seminaru istorykiv «Ukrainsko-polski vidnosyny v 1918 - 1947 rr.». Varshava, 22 - 24 travnia 1997 r. - 1998. - S. 11-28.

32. Kucherepa M. Pravoslavia na Volyni (1921 - 1939 rr.) / M. Kucherepa, V. Onishchuk // Zbirnyk navchalno-metodychnykh materialiv i naukovykh statei istorychnoho fakultetu. - Lutsk: Red.-vyd. viddil «Vezha» Volynskoho derzhavnoho universytetu im. Lesi Ukrainky, 1998. - № 3. - S. 73-77.

33. Makar Yu. Stanovyshche ukraintsiv u mizhvoiennii Polshchi / Yu. Makar // Chetvertyi mizhnarodnyi konhres ukrainistiv. Dopovidi ta povidomlennia. Istoriia. Chastyna 2: XX st. - Odesa - Kyiv - Lviv, 1989. - S. 480486.

34. Podolskyi A. Yu. Uroky mynuloho: Istoriia Holokostu v Ukraini: Navch. posibnyk / A. Yu. Podolskyi. K.: TOV «Sprynt-Servis», 2016. - $104 \mathrm{~s}$.

35. Politychna istoriia Ukrainy. XX stolittia: U 6-ty t. / [Redkol.: I. F. Kuras (holova) ta in.]. - K.: Heneza, 2002. - T. 5: Ukraintsi za mezhamy URSR (1918 - 1940) [Kerivnyk tomu V. P. Troshchynskyi]. - K., 2003. - 720 s.

36. Ruda O. Derzhavna polityka Druhoi Rechi Pospolytoi v natsionalnii sferi u 1918 - 1926 rokakh / O. Ruda // Problemy humanitarnykh nauk: zbirnyk naukovykh prats Drohobytskoho derzhavnoho pedahohichnoho universytetu imeni Ivana Franka. Seriia «Istoriia». - Drohobych, 2015. - Vypusk 36. - S. 160-174. 
37. Ruda O. V. Natsionalna polityka Polskoi derzhavy u 1926 - 1939 rokakh / O. V. Ruda // Naukovi pratsi istorychnoho fakultetu Zaporizkoho natsionalnoho universytetu. - Zaporizhzhia, 2015. - Vyp. 44. - Tom 2. S. $76-80$.

38. Savchuk B. Za Ukrainsku tserkvu. Natsionalno-tserkovnyi rukh na Volyni u 20 - 30-ti rr. XX st. / B. Savchuk. - Ivano-Frankivsk: Lileia-NV, 1997. - 116 s.

39. Soliar I. Ya. Zovnishni oriientatsii natsionalno-derzhavnytskykh partii Zakhidnoi Ukrainy (1923 - 1939): avtoref. dys. ... dokt. istor. nauk: spets. 07.00 .01 - istoriia Ukrainy / I. Ya. Soliar. - Ivano-Frankivsk, 2012. - 34 s.

40. Stokolos N. H. Konfesiino-etnichna transformatsiia v Ukraini (XIX - persha polovyna XX st.): Monohrafiia / N. H. Stokolos. - Rivne: RIS KSU - PPF «Lista-M», 2003. - 480 s.

41. Fedyk I. Natsionalna polityka mizhvoiennoi Polshchi v Halychyni: yevreiskyi kontekst (na prykladi diialnosti pravookhoronnykh orhaniv) / I. Fedyk // Naukovi zoshyty istorychnoho fakultetu Lvivskoho universytetu. 2012 - 2013. - Vypusk 13-14. - C. 589-595.

42. Fedyk I. UNDO, OUN: stavlennia do Polshchi / I. Fedyk. - Lviv: B. v., 1998. - 80 s.

43. Khonyhsman Ya. Katastrofa evreistva Zapadnoi Ukrainy. Evrey Vostochnoi Halytsyy, Zapadnoi Volyni, Bukovyny i Zakarpatia v 1933 - 1945 hodakh / Ya. Khonyhsman. - Lvov: B. y., 1998. - 352 s.

44. Shvahuliak M. «Patsyfikatsiia». Polska represyvna aktsiia u Halychyni 1930 roku i ukrainska suspilnist / M. Shvahuliak. - Lviv: Instytut ukrainoznavstva im. I. Krypiakevycha NAN Ukrainy, 1993. - $52 \mathrm{s.}$

45. Shvahuliak M. Lviv: vid stolytsi Zakhidnoukrainskoi derzhavy do politychnoho tsentru ukraintsiv Halychyny (1918 - 1939 rr.) / M. Shvahuliak // Lviv: misto - suspilstvo - kultura: Zbirnyk naukovykh prats. T. 3. Spetsialnyi vypusk Visnyka Lvivskoho universytetu. Seriia istorychna. - Lviv, 1999. - S. 469-492.

46. Shvahuliak M. Suspilno-politychna sytuatsiia u Zakhidnii Ukraini na pochatku 30-kh rokiv XX st. / M. Shvahuliak // Zapysky Naukovoho Tovarystva imeni Shevchenka. - Tom CCXXII. Pratsi istoryko-filosofskoi sektsii. - Lviv: NTSh, 1991. - S. 111-145.

47. Shumykhina S. O. Ukrainska istoriohrafiia mizhvoiennoi Polshchi $(1918-2012$ rr.): avtoref. dys. ... kand. istor. nauk: spets. 07.00 .06 - istoriohrafiia, dzhereloznavstvo ta spetsialni istorychni dystsypliny / S. O. Shumykhina. - K., 2013. $-16 \mathrm{~s}$.

48. Kuczerepa M. Stosunki ukraińsko-polskie w II Rzeczypospolitej we współczesnej historiografii ukraińskiej / M. Kuczerepa // Historycy Polscy i Ukraińscy wobec problemów XX wieku. - Kraków, 2000. - S. 146-165.

Стаття надійшла до редакиії 28.10.2017 p. 